\title{
Unconventional feeds for small ruminants in dry areas have a minor effect on manure nitrogen flow in the soil-plant system
}

\author{
Journal Article \\ Author(s): \\ Abbeddou, Souheila; Diekmann, J.; Rischkowsky, B.; Kreuzer, M.; Oberson, A. \\ Publication date: \\ 2013-01 \\ Permanent link: \\ https://doi.org/10.3929/ethz-b-000064141
}

Rights / license:

In Copyright - Non-Commercial Use Permitted

Originally published in:

Nutrient Cycling in Agroecosystems 95(1), https://doi.org/10.1007/s10705-013-9550-4 


\title{
Unconventional feeds for small ruminants in dry areas have a minor effect on manure nitrogen flow in the soil-plant system
}

\author{
S. Abbeddou • J. Diekmann • B. Rischkowsky • \\ M. Kreuzer $\cdot$ A. Oberson
}

Received: 1 May 2012/Accepted: 3 January 2013/Published online: 10 January 2013

(C) Springer Science+Business Media Dordrecht 2013

\begin{abstract}
In dry areas, unconventional feeds are increasingly used for mitigating feed shortages and rangeland degradation. We evaluated how feeding sheep diets containing olive leaves, saltbush leaves and olive cake affects manure quality compared to a barley straw based diet. Soil incubation and plant growth experiments were carried out to measure soil nitrogen (N) mineralization and $\mathrm{N}$ uptake by barley plants and to calculate $\mathrm{N}$ flow through the feed-animal-soil-plant system. Fresh feces, composts consisting of feces, urine and straw, and ammonium sulfate fertilizer were mixed with soil at rate of $90 \mathrm{mg} \mathrm{N} \mathrm{kg}^{-1}$ soil dry matter. Comparisons were made with non-amended soils (control) and soils amended with fresh olive cake applied at 90 and $22.5 \mathrm{mg} \mathrm{N} \mathrm{kg}^{-1}$ soil dry matter, respectively. The latter treatment enabled investigation of the effect of passage of olive cake through the digestive tract of sheep on $\mathrm{N}$ availability and phenol transformation. Applying fresh olive cake and feces, except the saltbush leaf derived feces, resulted in a net
\end{abstract}

S. Abbeddou $\cdot$ M. Kreuzer

Institute of Agricultural Sciences, Animal Nutrition, ETH

Zurich, Universitätsstrasse 2, 8092 Zurich, Switzerland

J. Diekmann · B. Rischkowsky

International Center for Agricultural Research in the Dry

Areas (ICARDA), Aleppo, Syria

A. Oberson $(\bowtie)$

Institute of Agricultural Sciences, Plant Nutrition, ETH

Zurich, Eschikon 33, 8315 Lindau, Switzerland

e-mail: astrid.oberson@usys.ethz.ch
$\mathrm{N}$ immobilization. All composts resulted in net $\mathrm{N}$ mineralization, although not significantly different from the $0 \mathrm{~N}$ control soil. Barley growing in soils with amendment that caused $\mathrm{N}$ immobilization took up less $\mathrm{N}$ than barley growing on the $0 \mathrm{~N}$ treatment. Reduction in $\mathrm{N}$ uptake was most pronounced after amendment with fresh-olive cake. Treatments with net mineralization increased barley $\mathrm{N}$ uptake over the $0 \mathrm{~N}$ treatment with $2-16 \%$ of $\mathrm{N}$ applied being taken up. Dietary composition had a minor effect on $\mathrm{N}$ fertilizer value of either feces or compost, but feces $\mathrm{N}$ alone was not an efficient $\mathrm{N}$ source.

Keywords Nitrogen efficiency - Manure - Compost · Saltbush - Olive by-product . Awassi sheep

\section{Introduction}

Under-utilized feeds like fodder shrubs and agroindustrial by-products are gaining attention in Mediterranean countries. Their importance lies in their potential role in overcoming animal feed shortages, mitigating rangeland degradation due to overgrazing, and in coping with increasing prices for traditional concentrate feeds and opportunity costs for growing forage on arable land. In dry areas mixed croplivestock systems with ruminants are common. The main crops are cereals, olive trees (the Mediterranean countries represent $98 \%$ of the global area planted with olive trees, Molina-Alcaide and Nefzaoui 1996), 
vegetables and cotton. In addition, in attempting to revegetate degraded and dry rangelands of the dry steppe areas, different saltbush species have been planted because of their tolerance of drought and salinity (Louhaichi and Tastad 2010). Previous studies showed that olive leaves and saltbush leaves constitute suitable forage resources during periods of shortage (e.g., Molina-Alcaide and Yáñez-Ruiz 2008; El Shaer 2010; Abbeddou et al. 2011a).

As a byproduct of the agro-food industry, 2.9 million tons per year of a ligno-cellulosic organic material results from olive oil production (Sansoucy 1985; Sellami et al. 2008). This residue is called olive cake. Studies have addressed its use as an energy source (Oktay 2006), as an animal feed (e.g., MolinaAlcaide and Yáñez-Ruiz 2008; Abbeddou et al. 2011b) or investigated composting before applying it as a soil amendment (e.g., Cayuela et al. 2004; Sellami et al. 2008). Still, it is mostly discarded as a waste and disposed in a non-sustainable manner in the olive oil production areas, where it constitutes an environmental issue because of its composition, large quantities and seasonality (Benitez et al. 2004; Roig et al. 2006).

Soil degradation is increasing in many Mediterranean countries (Benitez et al. 2004). Restoring soil fertility is closely linked to increasing soil organic matter and managing nutrient cycling (Frossard et al. 2006; Sommer et al. 2011). Animal manure is a valuable nitrogen $(\mathrm{N})$ source for crops, although with lower immediate $\mathrm{N}$ use efficiency (NUE) by crops than water soluble mineral N (Langmeier et al. 2002; Bosshard et al. 2009). However, organic matter (OM) content and microbial activity are higher in soils regularly receiving animal manure than in soils receiving exclusively mineral fertilizers (Fliessbach et al. 2007; Sommer et al. 2011). It is, however, unclear whether amendments resulting from different feeding options affect soil microbial activity and the NUE by the crops. Previous research indicated that the type of feed affects the availability of $\mathrm{N}$ contained in cow feces (e.g., dairy cow diets fed in the Midwest USA; Powell et al. 2006), and the phosphorus (P) content of manure (e.g., sheep fed with bush straw and millet stover; Sangaré et al. 2002) and subsequently, on nutrient uptake by plants from soils amended with these manures (Sangaré et al. 2002; Powell et al. 2006). The availability of manure $\mathrm{N}$ to crops could even be more dependent on feed type when feeds contain secondary plant metabolites like phenols. Phenols present in certain feeds may inhibit $\mathrm{N}$ availability and nutrient utilization in the animal (Abbeddou et al. 2011b) as well as $\mathrm{N}$ mineralization when the feed is applied directly to soils (Benitez et al. 2004; Cayuela et al. 2004). Feeding animals with plants rich in phenols also affected nutrient cycling by reducing $\mathrm{N}$ content in urine (Powell et al. 1994). Phenols bind to proteins to form indigestible complexes, which result in less excretion of $\mathrm{N}$ in urine and, additionally, a shift from soluble to insoluble $\mathrm{N}$ in the feces (Powell et al. 1994). In contrast, Rufino et al. (2006) did not find a correlation between the phenolic content of the manure and $\mathrm{N}$ mineralization.

The present study tested the following hypotheses: (1) Feeding sheep with certain unconventional feeds (olive leaves, saltbush leaves and olive cake) or the conventionally used barley straw affects manure quality in terms of content and availability of nutrients. (2) Fresh feces, composts (prepared from these feces, urine and barley straw), and fresh olive cake differ in their effect on soil $\mathrm{N}$ mineralization and $\mathrm{N}$ use by barley plants. These hypotheses were tested in soil incubation and plant experiments in the greenhouse by measuring $\mathrm{N}$ mineralization, $\mathrm{N}$ use by barley plants, and $\mathrm{N}$ flow through the feed-animal-soil-plant system.

\section{Materials and methods}

Feeding treatments and manure collection

Four groups of six growing Awassi lambs each were fed diets where large proportions of a traditional barley straw based diet (control) were replaced either by sun-dried leaves (with small twigs) from olive trees (Olea europaea L.), or from saltbush shrubs (Atriplex halimus), or air-dried olive cake from the first pressing containing also hulls and kernels. The animals received $1.1 \mathrm{~kg}$ dry matter $(\mathrm{DM})$ feed per day that covered their maintenance requirements. The composition of the diets is shown in Table 1 . The $\mathrm{N}$ contents of the four complete diets were in the range of $24.9 \pm 0.9 \mathrm{~g} \mathrm{~kg}^{-1} \mathrm{DM}$, with the barley straw, olive leaves, saltbush leaves and olive cake contributing 5.0, $10.7,18.5$ and $6.2 \mathrm{~g} \mathrm{~N} \mathrm{~kg}^{-1} \mathrm{DM}$, respectively. After a 15-day adaptation to the diets, the animals were held in metabolic crates over 10 days during which all feces (separated from urine) were collected, pooled per group and stored at $-20{ }^{\circ} \mathrm{C}$ until use. Urine was collected for 2 days, also pooled per group and stored 
for 2 weeks at $+4{ }^{\circ} \mathrm{C}$ until use. Further details about the sheep study are given in Abbeddou et al. (2011a, b).

\section{Manure composting procedure}

A method of composting manure at a laboratory scale was adapted from Thomsen (2000) with slight modifications. For the barley straw, olive leaves and olive cake diets, mixtures of feces, urine and barley straw were prepared in a fresh weight ratio of 10:2:1. As the feces from the saltbush diet had higher moisture content, more straw was added (fresh weight ratio of 10:2:2). These ratios resulted in moist mixtures approaching the maximum urine holding capacity of straw bedding which has accumulated feces in barns housing sheep. The excreta from the barley straw, olive leaves, saltbush leaves and olive cake diets mixed with barley straw gave initial ratios of feces, urine and straw $\mathrm{N}$ of 10.6:2.5:1, 17.7:2.4:1, 3.2:0.4:1; 11.3:2.6:1, respectively. Each feces-urine-straw mixture was composted separately under aerobic conditions by placing $52 \mathrm{~kg}$ of each mixture $(56 \mathrm{~kg}$ for the saltbush diet) in a jute bag with open mesh. These bags were placed on wooden pallets, in a room where the temperature was maintained between 20 and $25^{\circ} \mathrm{C}$ for 18 weeks. During the composting process, the temperature was recorded weekly. Likewise, the moisture content was adjusted to $450-650 \mathrm{~g} \mathrm{~kg}^{-1} \mathrm{DM}$ after having determined the water content, and the mixture was turned manually with a spade, before being placed back into the bags. A subsample of the each compost mixture was collected weekly and stored at $-20{ }^{\circ} \mathrm{C}$ until analysis. The bags were weighed at the end of the composting.

\section{Soil and preliminary plant experiment}

Soil with a low mineral $\mathrm{N}$ content was sampled from the upper $20 \mathrm{~cm}$ of a field under a chickpea-cereal rotation after chickpea harvesting at the International Center for Agricultural Research in the Dry Areas (ICARDA), Syria. The soil (Table 2), classified as very fine, montmorillonitic, thermic, Chromic Calcixerert (Ryan et al. 1997), was collected using a mechanical soil auger. It was sieved through a mesh $(<2 \mathrm{~mm})$ to obtain a homogenous soil, kept moist and stored at room temperature until the soil incubation and plant growth experiments were established.

In a preliminary experiment, the amount of $\mathrm{N}$ amendment to be used for the incubation and the plant experiments was determined. A plant NUE response curve to mineral $\mathrm{N}$ fertilization was measured from applications of $0,45,90,135,270$ and $405 \mathrm{mg} \mathrm{N} \mathrm{kg}^{-1}$ soil after 7 weeks of growth. Ammonium sulfate was used as the mineral amendment, barley as the test crop and each dose was repeated in quadruplicate. The NUE (see Eq. 1, below) was plotted against the

Table 1 Description of feeding trials and composition of the diets fed to fat-tailed Awassi sheep

\begin{tabular}{|c|c|c|c|}
\hline Feeding trial & Diet & Feed component description $\left(\mathrm{g} \mathrm{kg}^{-1} \mathrm{DM}\right)$ & Nutrients content in feed \\
\hline \multirow[t]{3}{*}{$\begin{array}{l}\text { Barley straw replaced } \\
\text { with olive leaves or } \\
\left.\text { saltbush leaves }{ }^{\mathrm{a}}\right)\end{array}$} & Barley straw & $\begin{array}{l}716 \mathrm{~g} \text { barley straw, } 176 \mathrm{~g} \text { cotton seed meal, } \\
88 \mathrm{~g} \text { molasses, and } 20 \mathrm{~g} \text { mineral-vitamin mix. } \\
16 \mathrm{~g} \text { urea } \mathrm{kg}^{-1} \mathrm{DM}\end{array}$ & $\begin{array}{l}\text { DM: } 1,100 \mathrm{~g} \\
\text { CP: } 159 \mathrm{~g} \mathrm{~kg}^{-1} \mathrm{DM} \\
\text { Metabolisable energy: } 7.59 \mathrm{MJ} \mathrm{kg}^{-1} \mathrm{DM}\end{array}$ \\
\hline & Olive leaf & $\begin{array}{l}716 \mathrm{~g} \text { olive leaves, } 44 \mathrm{~g} \text { barley grain, } 44 \mathrm{~g} \\
\text { wheat bran, } 88 \mathrm{~g} \text { cotton seed meal, } 88 \mathrm{~g} \\
\text { molasses, and } 20 \mathrm{~g} \text { mineral-vitamin mix. } 11 \mathrm{~g} \\
\text { urea } \mathrm{kg}-1 \mathrm{DM}\end{array}$ & $\begin{array}{l}\text { DM: } 1,100 \mathrm{~g} \\
\mathrm{CP}: 157 \mathrm{~g} \mathrm{~kg}^{-1} \mathrm{DM} \\
\text { Metabolisable energy: } 7.85 \mathrm{MJ} \mathrm{kg}^{-1} \mathrm{DM}\end{array}$ \\
\hline & Saltbush leaf & $\begin{array}{l}716 \mathrm{~g} \text { saltbush leaves, } 44 \mathrm{~g} \text { barley grain, } 132 \mathrm{~g} \\
\text { wheat bran, } 88 \mathrm{~g} \text { molasses, and } 20 \mathrm{~g} \text { mineral- } \\
\text { vitamin mix. } 2 \mathrm{~g} \text { urea } \mathrm{kg}^{-1} \mathrm{DM}\end{array}$ & $\begin{array}{l}\text { DM: } 1,100 \mathrm{~g} \\
\text { CP: } 159 \mathrm{~g} \mathrm{~kg}^{-1} \mathrm{DM} \\
\text { Metabolisable energy: } 7.59 \mathrm{MJ} \mathrm{kg}^{-1} \mathrm{DM}\end{array}$ \\
\hline $\begin{array}{l}\text { Concentrate replaced } \\
\text { with olive cake }{ }^{b}\end{array}$ & Olive cake & $\begin{array}{l}490 \mathrm{~g} \text { barley straw, } 340 \mathrm{~g} \text { olive cake, } 100 \mathrm{~g} \\
\text { cotton seed meal, } 50 \mathrm{~g} \text { molasses, } 20 \mathrm{~g} \\
\text { mineral-vitamin mix. } 19 \mathrm{~g} \text { urea } \mathrm{kg}^{-1} \mathrm{DM}\end{array}$ & $\begin{array}{l}\text { DM: } 1,100 \mathrm{~g} \\
\mathrm{CP}: 147 \mathrm{~g} \mathrm{~kg}^{-1} \mathrm{DM} \\
\text { Metabolisable energy: } 5.50 \mathrm{MJ} \mathrm{kg}^{-1} \mathrm{DM}\end{array}$ \\
\hline
\end{tabular}

\footnotetext{
a For details see Abbeddou et al. (2011a)

b For details see Abbeddou et al. (2011b)
} 
amount of ammonium sulfate applied. The maximal NUE was found at a dose of $90 \mathrm{mg} \mathrm{N} \mathrm{kg}^{-1}$ soil, which was then used in the following experiments.

Soil response to the different amendments

The experimental soil was mixed manually with $\mathrm{N}$-free nutrient solutions in order to avoid macroand micronutrient deficiencies. Mineral compounds supplied to the soil were $\left(\mathrm{mg} \mathrm{kg}^{-1}\right.$ soil $\left.\mathrm{DM}\right): \mathrm{KCl}$ (85.8), $\quad \mathrm{KH}_{2} \mathrm{PO}_{4}$ (395.4), $\mathrm{CaCl}_{2} \quad$ (55.1), $\quad \mathrm{MgSO}_{4}$ (162.2), $\mathrm{ZnSO}_{4}$ (4.4), $\mathrm{Na}_{2} \mathrm{MoO}_{4}(0.20)$, Fe chelate (6.2), $\mathrm{H}_{3} \mathrm{BO}_{3}$ (5.7), $\mathrm{MnSO}_{4}$ (6.2), $\mathrm{CuSO}_{4}$ (7.9) and $\mathrm{CoSO}_{4}$ (0.48). The soil was mixed with amendment (feces from the four diets, four composts and olive cake; 9 treatments), or ammonium sulfate fertilizer in quantities equivalent to $90 \mathrm{mg} \mathrm{N} \mathrm{kg}^{-1}$ dry soil. Fresh olive cake was also tested at $22.5 \mathrm{mg} \mathrm{N} \mathrm{kg}^{-1}$ soil. Control treatment $(0 \mathrm{~N})$ soil received only the $\mathrm{N}$-free nutrient solutions but no amendment. The amendment, fertilizer and control soil mixtures were transferred to a total of 288 plastic pots (12 treatments $\times 4$ replicates $\times 6$ sampling times) each with a volume of $100 \mathrm{ml}$. The water content was brought to $350 \mathrm{~g} \mathrm{~kg}^{-1} \mathrm{DM}$ of the soil. The pots were stored at $25{ }^{\circ} \mathrm{C}$ in a growth chamber in the dark. Lost water was replaced with distilled water every second day by restoring the initial weight of the pots. Four pots from each treatment were withdrawn at every sampling time, i.e., after 1 day, and 1, 2, 4, 7 and 12 weeks. Soils were analyzed immediately afterwards.

Plant response to the experimental amendments

The effect of the amendments on $\mathrm{N}$ uptake was assessed by using barley (Hordeum vulgare L., var. Harmal) as a test plant. For this, 48 pots (12 treatments $\times 4$ replicates) were filled with $900 \mathrm{~g}$ soil
DM prepared and amended as previously described for the soil incubation experiment, except that ammonium sulfate was split in two doses, namely $30 \mathrm{mg} \mathrm{N} \mathrm{kg}^{-1}$ soil DM at sowing and $60 \mathrm{mg} \mathrm{N} \mathrm{kg}^{-1}$ soil DM at tillering. Barley seeds treated with a fungizide (Vitavax $200 \mathrm{FF}$, Chemtura, Italy) were sown at a rate of 10 seeds pot $^{-1}$ with a distance of $2 \mathrm{~cm}$ between seeds. The seeded pots were watered to $350 \mathrm{~g} \mathrm{~kg}^{-1} \mathrm{DM}$ soil and transferred to a greenhouse set to $14 \mathrm{~h}$ daylight at $25^{\circ} \mathrm{C}$ and $10 \mathrm{~h}$ darkness at $15^{\circ} \mathrm{C}$. The pots were watered every other day as described for the soil incubation experiment. After 7 weeks of growth, which was at the end of the vegetative stage, the shoots were cut at $1 \mathrm{~cm}$ above the soil surface and dried immediately at $65{ }^{\circ} \mathrm{C}$ for $48 \mathrm{~h}$. The pots were emptied and the roots were washed from the soil under a water-jet, and then also dried at $65{ }^{\circ} \mathrm{C}$ for $48 \mathrm{~h}$.

Chemical analyses

Feces, compost samples collected during the 18 week composting period, and olive cake were analyzed by standard methods (AOAC 1997) for DM and OM (AOAC index no. 942.05), total N (AOAC 977.02) and, total $\mathrm{C}$ with a $\mathrm{C} / \mathrm{N}$ analyzer (AOAC index no. 977.02). Total phenols were measured in the fresh feces, mature compost and fresh olive cake using the Folin Ciocalteu method (Makkar 2003). Feces and composts were also analyzed for their mineral $\mathrm{N}$ content $\left(\mathrm{NO}_{3}{ }^{-}\right.$extracted by deionized water and $\mathrm{NH}_{4}{ }^{+}$ extracted with $2 \mathrm{M} \mathrm{KCl}$, Bremner and Keeney 1965 , and analyzed by titration with diluted $\mathrm{H}_{2} \mathrm{SO}_{4}$, Keeney and Nelson 1982) as well as total P and K after wet digestion using nitric and perchloric acids (AOAC 935-13) and analyzed using a UV-Vis spectrophotometer (model U-2000, Hitachi, Tokyo, Japan; AOAC 965-17) for $\mathrm{P}$ and a digital flame analyzer (A. Gallenkamp and Co., London, UK; AOAC 969.23)

Table 2 Properties of the soil used in soil and plant growth experiments

\begin{tabular}{|c|c|c|c|c|c|c|c|c|c|c|}
\hline \multirow[t]{2}{*}{ Soil classification } & \multicolumn{3}{|c|}{ Texture $\left(\mathrm{g} \mathrm{kg}^{-1}\right)$} & \multicolumn{5}{|c|}{ Composition $\left(\mathrm{g} \mathrm{kg}^{-1} \mathrm{DM}\right)$} & \multirow[t]{2}{*}{$\mathrm{pH}$} & \multirow{2}{*}{$\begin{array}{l}\text { Electrical } \\
\text { conductivity } \\
\left(\mathrm{mS} \mathrm{cm}^{-1}\right)\end{array}$} \\
\hline & Clay & Silt & Sand & $\begin{array}{l}\text { Organic } \\
\text { matter }\end{array}$ & Total N & Mineral N & Olsen- $\mathrm{P}^{\mathrm{a}}$ & Extractable $\mathrm{K}^{\mathrm{b}}$ & & \\
\hline $\begin{array}{l}\text { Montmorillonitic, thermic, } \\
\text { chromic calcixerert }\end{array}$ & 539 & 283 & 178 & 10.4 & 0.78 & 0.01 & 0.012 & 0.27 & 8.2 & 0.271 \\
\hline
\end{tabular}


for K. Compost samples were mixed with water at a ratio of 1:5, and $\mathrm{pH}$ and electrical conductivity (EC) of the extract were measured using a $\mathrm{pH}$ meter ( $\mathrm{pH}$ M82, Radiometer, Copenhagen, Denmark) and a conductivity cell (CDM83, Radiometer, Copenhagen, Denmark), respectively. At every sampling date, samples of the incubated soils were analyzed for $\mathrm{pH}, \mathrm{EC}$ and mineral $\mathrm{N}_{\left(\mathrm{NO}_{3}\right.}{ }^{-}$and $\mathrm{NH}_{4}{ }^{+}$extracted as described by Bremner and Keeney 1965, and analyzed by sulfuric acid titration, Keeney and Nelson 1982). Only values recorded at the beginning and the end of the experiment are shown in tables, except for the time course of mineral N. In addition, soil samples collected at the end of the incubation experiment were analyzed for their OM (chromic acid titration method, Walkley 1947), extractable P (sodium bicarbonate extraction, Olsen et al. 1954) and $\mathrm{K}$ (ammonium acetate extraction, Richards 1954) contents. Barley shoots and roots were analyzed for DM and total N content by NCS elemental analyzer (Flash EA 1112 Series NCS analyzer, Thermo Electron Corporation, Waltham, USA).

Calculations and statistical analysis

From the incubation experiment, net $\mathrm{N}$ mineralization was calculated as the difference between the total mineral $\mathrm{N}$ at the end of the incubation time (12 weeks) and that at the beginning of the experiment (day 1). The net mineralization over the $0 \mathrm{~N}$ control is the net mineralization of the amendments tested minus the net mineralization of the control $(0 \mathrm{~N})$.

The NUE by barley for each of the amendments was computed by the difference method (Harmsen 2003) as:

$\operatorname{NUE}(\%)=100 \times\left(\mathrm{NP}_{\mathrm{a}}-\mathrm{NP}_{0 \mathrm{~N}}\right) / \mathrm{N}_{\mathrm{ai}}$

where $\mathrm{NP}_{\mathrm{a}}=$ total $\mathrm{N}$ uptake by amended plants (mg $\left.\operatorname{pot}^{-1}\right), \mathrm{NP}_{0 \mathrm{~N}}=$ total $\mathrm{N}$ uptake by unamended plants $\left(\mathrm{mg} \operatorname{pot}^{-1}\right.$ ) and $\mathrm{N}_{\mathrm{ai}}=$ total amount of the amendment $\mathrm{N}$ applied (mg pot $\left.{ }^{-1}\right)$.

Selected data from the associated animal experiment (Abbeddou et al. 2011a, b), including $\mathrm{N}$ intake, $\mathrm{N}$ excretion in feces and urine and the resulting $\mathrm{N}$ retention in the body were used in this study to estimate the $\mathrm{N}$ flows through the feed-animal-soil-plant system. Nitrogen cycling efficiency was calculated for each diet and was standardized to 1,000 $\mathrm{g} \mathrm{N}$ intake by the animals as follows.

The $\mathrm{N}$ excreted in feces and urine was expressed as a proportion of $\mathrm{N}$ intake:
Fecal $\mathrm{N}\left(\mathrm{g} \mathrm{kg}^{-1} \mathrm{~N}\right.$ intake $)=1,000$

$\times(\mathrm{N}$ excreted in feces $/ \mathrm{N}$ intake $)$

Urine $\mathrm{N}\left(\mathrm{g} \mathrm{kg}^{-1} \mathrm{~N}\right.$ intake $)=1,000$

$\times(\mathrm{N}$ excreted in urine $/ \mathrm{N}$ intake $)$

Excreted $\mathrm{N}\left(\mathrm{g} \mathrm{kg}^{-1} \mathrm{~N}\right.$ intake $)=$ Fecal $\mathrm{N}+$ Urine $\mathrm{N}$

Body $\mathrm{N}$ retention $\left(\mathrm{g} \mathrm{kg}^{-1} \mathrm{~N}\right.$ intake $)$

$=1,000-$ Excreted $\mathrm{N}$

$\mathrm{N}$ retained (fecal $\mathrm{N}$ and urine $\mathrm{N}$ in uncomposted mixture) from excretion collection, and unaccounted for in composting (i.e., not included in our experimental design), respectively, was calculated according to the formulas given by Rufino et al. (2006), except that they were all expressed based on 1,000 $\mathrm{g}$ $\mathrm{N}$ intake:

Fecal $\mathrm{N}$ in uncomposted mixture $\left(\mathrm{g} \mathrm{kg}^{-1} \mathrm{~N}\right.$ intake $)$ $=1,000 \times(\mathrm{N}$ feces used $/ \mathrm{N}$ intake $)$

Urine $\mathrm{N}$ in uncomposted mixture $\left(\mathrm{g} \mathrm{kg}^{-1} \mathrm{~N}\right.$ intake $)$ $=1,000 \times(\mathrm{N}$ urine used $/ \mathrm{N}$ intake $)$

Unaccounted $\mathrm{N}\left(\mathrm{g} \mathrm{kg}^{-1} \mathrm{~N}\right.$ intake $)=$ Excreted $\mathrm{N}$

- (Fecal $\mathrm{N}$ in uncomposted mixture

+ Urine $\mathrm{N}$ in uncomposted mixture)

At the final stage of composting, $\mathrm{N}$ efficiency was calculated as the amount of $\mathrm{N}$ in compost as a proportion of $\mathrm{N}$ contained in the fresh feces and urine used in the mixture for composting, and in relation to $\mathrm{N}$ intake:

$\mathrm{N}$ retained during composting $\left(\mathrm{g} \mathrm{kg}^{-1} \mathrm{~N}\right.$ intake $)$

$=1,000 \times(\mathrm{N}$ in compost $/$ Fecal $\mathrm{N}$ and

Urine $\mathrm{N}$ in uncomposted mixture)/ $\mathrm{N}$ intake

$\mathrm{N}$ lost during composting $\left(\mathrm{g} \mathrm{kg}^{-1} \mathrm{~N}\right.$ intake $)$

$=\mathrm{N}$ in uncomposted mixture $-\mathrm{N}$ in compost

For plant $\mathrm{N}$ uptake, $\mathrm{N}$ flow was calculated as the amount of $\mathrm{N}$ in the plant as a proportion of the amount of $\mathrm{N}$ applied to the soil with the amendment (feces or compost) again reported as $\mathrm{g} \mathrm{kg}^{-1} \mathrm{~N}$ intake of the animal. 
Plant $\mathrm{N}$ uptake $\left(\mathrm{g} \mathrm{kg}^{-1} \mathrm{~N}\right.$ intake $)$

$$
=\mathrm{NUE}(\%) / 100 \times \text { amendment } \mathrm{N}\left(\mathrm{g} \mathrm{kg}^{-1} \mathrm{~N} \text { intake }\right)
$$

where amendment $\mathrm{N}$ is either the fecal $\mathrm{N}$ (when feces are used as treatment) or $\mathrm{N}$ retained during composting (result from Eq. 9 when compost is used as treatment).

The GLM procedure (SAS version 9.2, SAS Institute Inc., Cary, NC) was used for analysis of variance of the data from the incubation and the plant experiments, with amendment as a fixed factor. Means were compared with the Tukey test at $P<0.05$. The tables give arithmetic means, standard errors of the means and $P$ values. Changes in total mineral $\mathrm{N}$ in the incubation experiment were analyzed by repeated measurement analysis using the GLM procedure of SAS. Treatment, time and the interaction between the two were considered as fixed factors. Figure 1 gives least square means, standard errors and $P$ values.

\section{Results}

Composition of the amendments and changes during the composting process

The mean OM content of the amendments (feces, compost and fresh olive cake) ranged from 683 to $900 \mathrm{~g} \mathrm{~kg}^{-1} \mathrm{DM}$ (Table 3), and was lowest for the saltbush leaf compost, and highest for olive cake derived feces, uncomposted mixture and compost derived from this diet. The $\mathrm{C} / \mathrm{N}$ ratio was on average 25 for fresh feces and 13 for compost and as high as 39 for the fresh olive cake. Accordingly, feces from the olive cake treatment also had a particularly high $\mathrm{C} / \mathrm{N}$ ratio. Mineral $\mathrm{N}$ content $\left(\mathrm{NH}_{4}-\mathrm{N}\right.$ and $\left.\mathrm{NO}_{3}-\mathrm{N}\right)$ tended to be lower in the composts than the corresponding fresh feces, except for compost from barley straw diet. The $\mathrm{K}$ content was higher in the composts than in the fresh feces. Likewise $\mathrm{P}$ content was higher in the composts, except for saltbush leave compost. On average, total phenol content in the composts, ranging between 1 and $2 \mathrm{~g} \mathrm{~kg}^{-1} \mathrm{DM}$, was lower than in the feces and the fresh olive cake. Total phenol content in the composts represented on average only $33 \%$ of the content in feces from barley straw, olive leaf, saltbush leaf and olive cake diets.
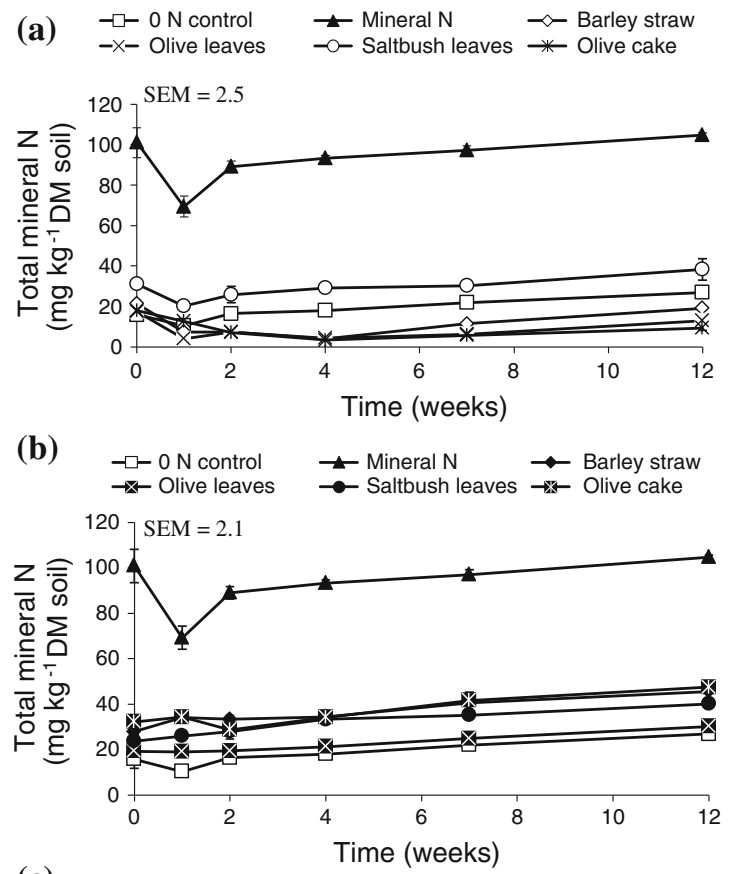

(c)
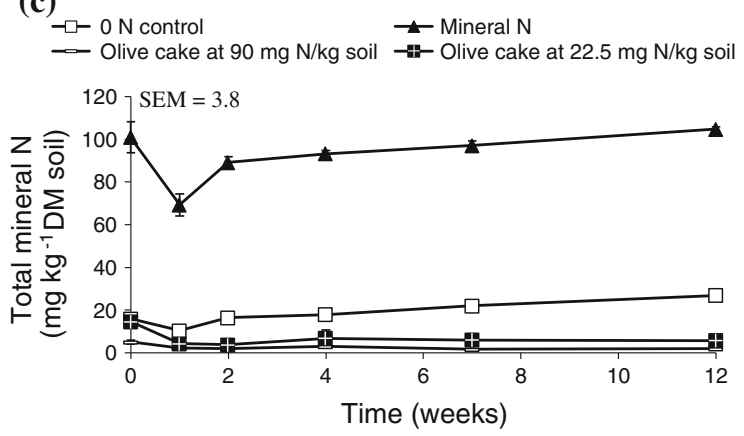

Fig. 1 Changes in total mineral $\mathrm{N}\left(\mathrm{mg} \mathrm{kg}^{-1} \mathrm{DM}\right)$ of unamended soil ( $0 \mathrm{~N}$ ), soil amended with mineral $\mathrm{N}$ (ammonium sulfate), soil amended with feces from sheep fed barley straw, olive leaves, saltbush leaves or fresh olive cake (a); soil amended with compost made from the feces and urine of sheep fed these four diets (b); and soil amended with fresh olive cake at $90 \mathrm{mg} \mathrm{N} \mathrm{kg}^{-1}$ and $22.5 \mathrm{mg} \mathrm{N} \mathrm{kg}{ }^{-1}$ (c). Amendment, $P<0.001$; week, $P<0.001$; amendment $\times$ week, $P<0.001$, SEM at treatment level $=1.9$

The temperature in the compost bags increased from an average of $7-55{ }^{\circ} \mathrm{C}$ during the first 3 days (data not shown). The differences in chemical composition between the uncomposted mixtures at the beginning of the composting procedure were largely present at the end of the composting, except for $\mathrm{pH}$ and EC. The initial weight of the uncomposted mixture of $52 \mathrm{~kg}$ (56 kg for the saltbush treatment) corresponded to 16 , 20,13 and $23 \mathrm{~kg}$ on DM basis for composts prepared from the excreta of the sheep fed the barley straw, olive 


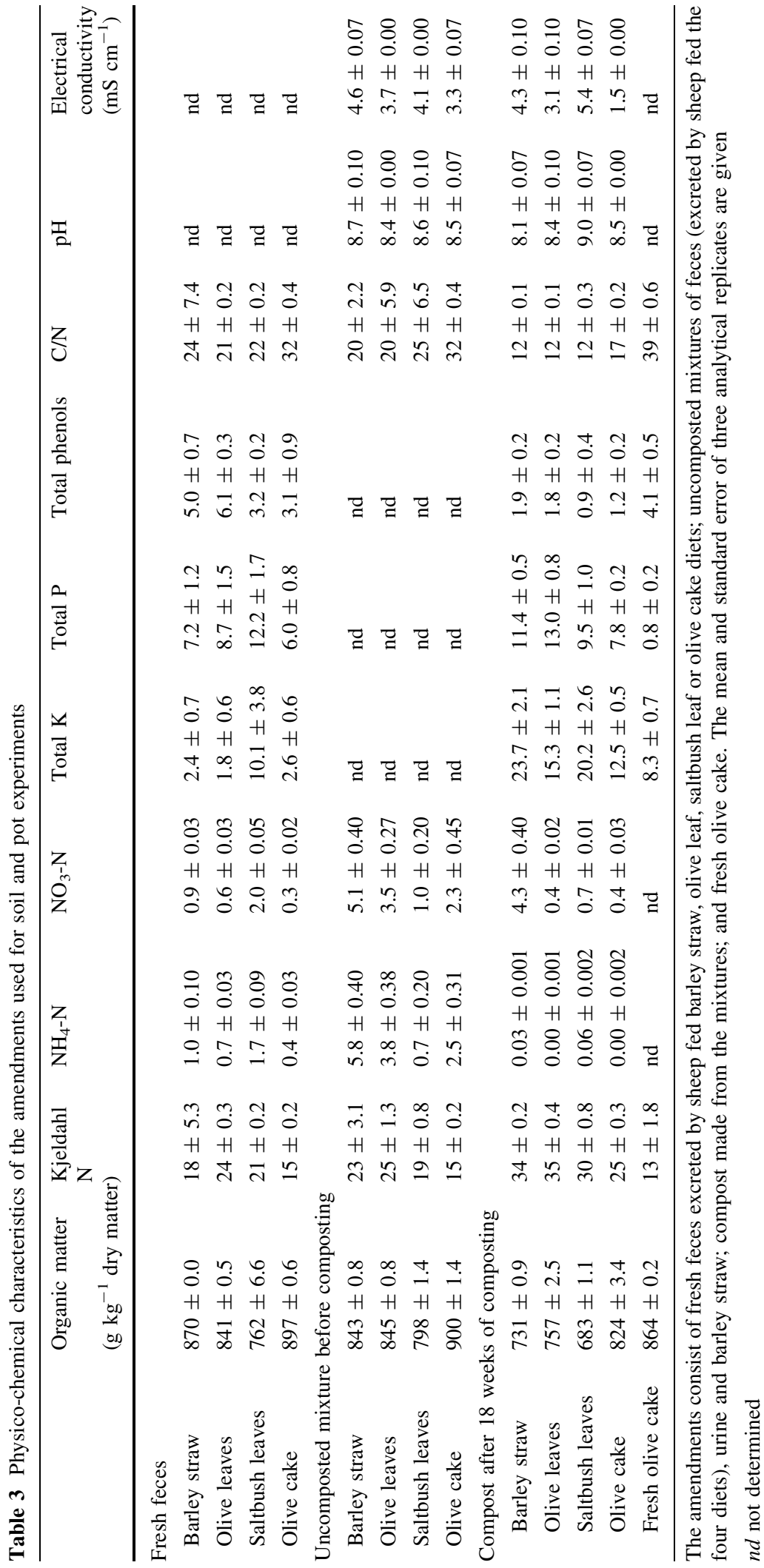


leaf, saltbush leaf and olive cake diets, respectively. The corresponding DM losses during composting were $687,450,461$ and $565 \mathrm{~g} \mathrm{~kg}^{-1}$ initial DM (data not shown), with OM losses of 729, 507, 539 and $602 \mathrm{~g} \mathrm{~kg}^{-1}$ initial OM, respectively. The decline in OM content was most pronounced with the saltbush leaf and the barley straw treatments (Table 3). The decline in OM was lowest with compost from the olive cake diet and intermediate with the compost from the olive leaf diet. Total $\mathrm{N}$ content per unit of DM increased during composting, and the $\mathrm{C} / \mathrm{N}$ ratio of the four composts decreased from a range of 20 to 32 to between 12 and 17. Contents of both $\mathrm{NH}_{4}-\mathrm{N}$ and $\mathrm{NO}_{3}-\mathrm{N}$ decreased during the composting process except for the barley straw treatment. While the $\mathrm{pH}$ did not change during composting of the excreta obtained from olive leaf and olive cake fed sheep, it decreased for the barley straw diet and increased with the saltbush leaf diet. In all composts, except that produced from feeding the saltbush leaf diet, EC decreased with time.

\section{Soil response to the different amendments}

In general, all feces and compost amendments increased the OM contents of the soils, which amounted to greater than $1 \mathrm{~g} \mathrm{~kg}^{-1}$ soil DM on average compared to $0 \mathrm{~N}$ soil at the end of the incubation period (Table 4). This increase was about 5 times higher with the amendment with fresh olive cake when provided at the full $\mathrm{N}$ dose level. The quantities of OM added per $\mathrm{kg}$ soil with the amendments were in the range of 3-5 g with fresh feces, 2-3 g with composts and 8 or $2 \mathrm{~g}$ with fresh olive cake provided at the full or the $1 / 4 \mathrm{~N}$ dose.

Feces, except that from the saltbush leaf treatment, and fresh olive cake (at any dose) resulted in lower mineral $\mathrm{N}$ levels than in the $0 \mathrm{~N}$ soil during the 12 week incubation time (amendment $\times$ week, $P<0.001$ ), i.e., caused immobilization of $\mathrm{N}$ (Fig. 1). In contrast, composts and feces from the saltbush leaf treatment increased mineral $\mathrm{N}$ content over the $0 \mathrm{~N}$ control, although for $\mathrm{NH}_{4}-\mathrm{N}$ not significantly (Fig. 1; Table 4). Mineral $\mathrm{N}\left(\mathrm{NH}_{4}-\mathrm{N}\right.$ and $\left.\mathrm{NO}_{3}-\mathrm{N}\right)$ in the $0 \mathrm{~N}$ soil increased from 16 to $27 \mathrm{mg} \mathrm{kg}^{-1}$ soil DM from 1 day to 12 weeks incubation (Fig. 1). Compared to this change, differences in mineralization caused by the application of the organic amendments were small (Table 4). Net mineralization in compost treatments was not significantly different from the $0 \mathrm{~N}$ treatment while fresh feces amendments caused significant immobilization, except for the saltbush leave treatment. Amendments of the saltbush leaf treatments (feces and compost) and compost of barley straw treatment resulted in significant increases in extractable $\mathrm{K}$ compared to the $0 \mathrm{~N}$ soil. Finally, only amendment with saltbush leaf feces significantly increased soil $\mathrm{P}$ compared to the $0 \mathrm{~N}$ soil.

The non $\mathrm{N}$ amended soil had a $\mathrm{pH}$ of 8.4 at the start of the soil incubation experiment. Only few amendments affected $\mathrm{pH}$ significantly, which were barley straw feces, olive cake compost and fresh olive cake at any dose (Table 4). Changes in $\mathrm{pH}$ during the incubation period were small with only an increase or decrease of up to 0.2 units. The EC was $0.16 \mathrm{mS} \mathrm{cm}^{-1}$ in the $0 \mathrm{~N}$ soil at the beginning, but increased to $0.27 \mathrm{mS} \mathrm{cm}^{-1}$ at the end of the incubation period. Changes compared to the $0 \mathrm{~N}$ soil ranged between 0.02 and $0.15 \mathrm{mS} \mathrm{cm} \mathrm{cm}^{-1}$ directly upon amendment application, and between 0.06 and $0.27 \mathrm{mS} \mathrm{cm}^{-1}$ at the end of the incubation period. However, EC was significantly higher after incubation of soil amended with mineral fertilizer N, feces and compost of the saltbush leaf and the barley straw treatments, and olive cake compost.

Plant response to the experimental amendments

Total (shoot plus root) barley DM yield was $2.5 \mathrm{~g}$ for plants growing on the $0 \mathrm{~N}$ soil (Table 5). The addition of mineral $\mathrm{N}$ fertilizer caused a 1.7-fold increase in yield. Likewise, $\mathrm{N}$ yields per pot in shoot and root biomass were increased by mineral $\mathrm{N}$ addition. In contrast, the addition of the fresh feces of any origin did not affect or even tended to decrease DM yield compared to $0 \mathrm{~N}$, except for the saltbush leaf treatment, which increased shoot and total DM yields by 1.3- and 1.2-fold levels of $0 \mathrm{~N}$, respectively. Composts prepared from the barley straw and saltbush leaf treatment increased total DM yields by 1.4- and 1.2-fold respectively. The low and the high dose of fresh olive cake reduced total DM yield by 0.5 - and 0.3 -fold compared to $0 \mathrm{~N}$. The $\mathrm{N}$ uptake of barley followed the same trend as DM yield, resulting in a negative NUE for three of the fresh feces (i.e., those derived from the barley straw, olive leaf and olive cake diets) and fresh olive cake applied at both doses. The NUE was positive with the composts but low, ranging from $2 \%$ (olive cake diet derived compost) to $16 \%$ (barley straw diet derived compost). 


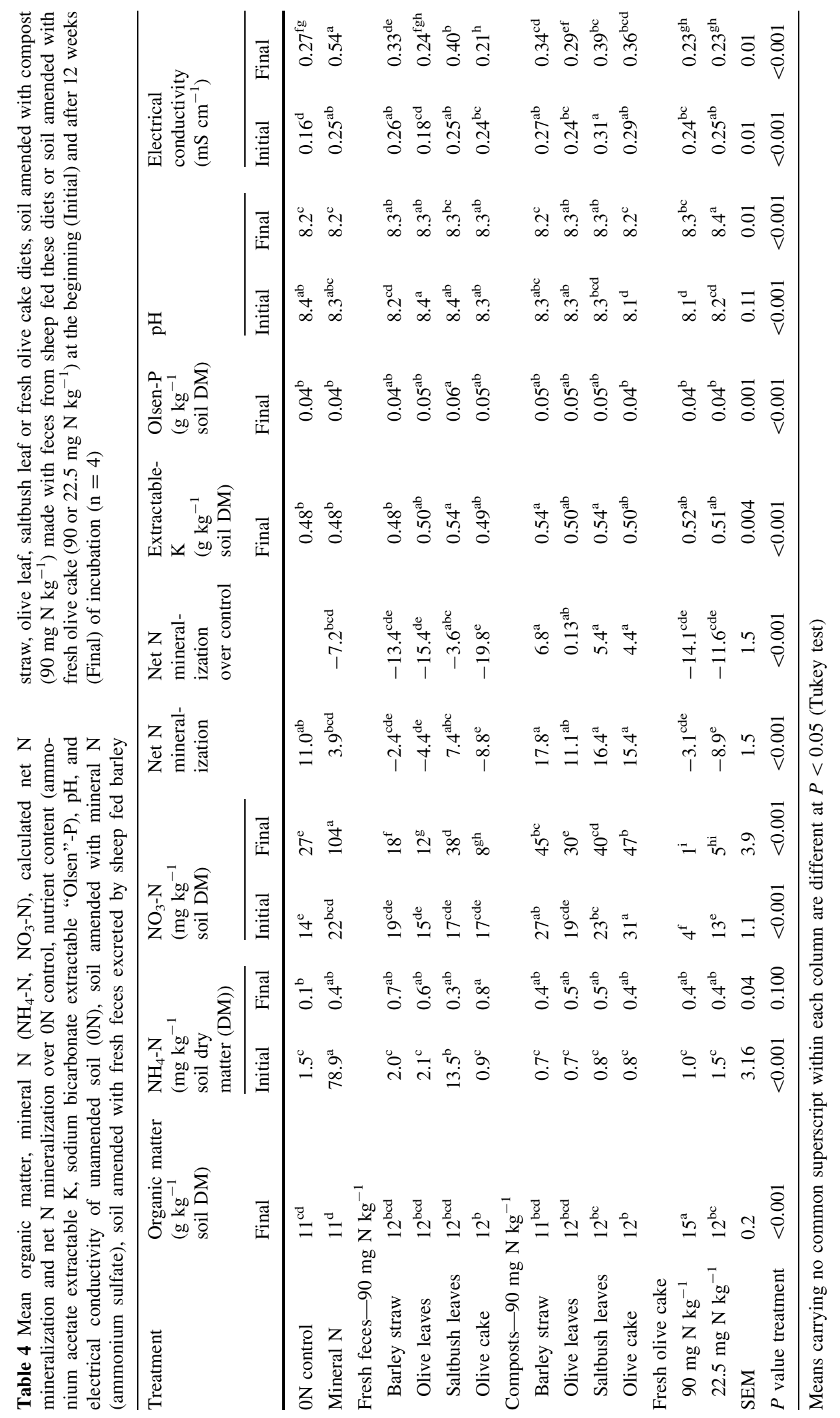


Table 5 Mean dry matter (DM), N yield and $\mathrm{N}$ use efficiency by barley grown on unamended soils $(0 \mathrm{~N})$, soil amended with mineral $\mathrm{N}$ (ammonium $\mathrm{N}$ ), soils amended with fresh feces excreted by sheep consuming barley leaves, olive leaves,

\begin{tabular}{|c|c|c|c|c|c|c|c|c|c|}
\hline \multirow[t]{2}{*}{ Treatment } & \multicolumn{3}{|l|}{$\mathrm{DM}(\mathrm{g})$} & \multicolumn{3}{|c|}{$\mathrm{N}$ yield $\left(\mathrm{mg}\right.$ pot $\left.^{-1}\right)$} & \multicolumn{3}{|c|}{$\mathrm{N}$ use efficiency $(\%)^{\psi}$} \\
\hline & Shoot & Root & Total & Shoot & Root & Total & Shoot & Root & Total \\
\hline ON control & $1.2^{\mathrm{d}}$ & $1.3^{\mathrm{cd}}$ & $2.5^{\mathrm{d}}$ & $14^{\mathrm{c}}$ & $9^{\text {ef }}$ & $23^{\mathrm{c}}$ & & & \\
\hline Mineral N & $2.5^{\mathrm{a}}$ & $1.6^{\mathrm{ab}}$ & $4.1^{\mathrm{a}}$ & $62^{\mathrm{a}}$ & $23^{\mathrm{a}}$ & $85^{\mathrm{a}}$ & $60^{\mathrm{a}}$ & $17^{\mathrm{a}}$ & $77^{\mathrm{a}}$ \\
\hline \multicolumn{10}{|l|}{ Fresh feces } \\
\hline Barley straw & $0.7^{\mathrm{e}}$ & $1.0^{\mathrm{ef}}$ & $1.6^{\mathrm{e}}$ & $8^{\mathrm{d}}$ & $9^{\text {efg }}$ & $17^{\mathrm{d}}$ & $-7^{\mathrm{d}}$ & $-1^{\text {ef }}$ & $-8^{\mathrm{d}}$ \\
\hline Olive leaves & $0.5^{\mathrm{f}}$ & $0.8^{\mathrm{f}}$ & $1.4^{\mathrm{ef}}$ & $7^{\text {de }}$ & $7^{\mathrm{fg}}$ & $14^{\mathrm{d}}$ & $-9^{\text {de }}$ & $-3^{f}$ & $-11^{\mathrm{d}}$ \\
\hline Saltbush leaves & $1.6^{\mathrm{bc}}$ & $1.4^{\mathrm{bc}}$ & $3.0^{\mathrm{c}}$ & $20^{\mathrm{b}}$ & $13^{\mathrm{bcd}}$ & $32^{\mathrm{b}}$ & $7^{\mathrm{b}}$ & $4^{\mathrm{bcd}}$ & $11^{\mathrm{b}}$ \\
\hline Olive cake & $0.7^{\mathrm{e}}$ & $0.8^{\mathrm{f}}$ & $1.5^{\mathrm{ef}}$ & $8^{\mathrm{d}}$ & $7^{\mathrm{fg}}$ & $15^{\mathrm{d}}$ & $-7^{\mathrm{d}}$ & $-3^{\mathrm{f}}$ & $-10^{\mathrm{d}}$ \\
\hline \multicolumn{10}{|l|}{ Compost } \\
\hline Barley straw & $1.7^{\mathrm{b}}$ & $1.8^{\mathrm{a}}$ & $3.4^{\mathrm{b}}$ & $21^{\mathrm{b}}$ & $16^{\mathrm{b}}$ & $36^{\mathrm{b}}$ & $8^{\mathrm{b}}$ & $8^{\mathrm{b}}$ & $16^{\mathrm{b}}$ \\
\hline Olive leaves & $1.3^{\mathrm{d}}$ & $1.3^{\mathrm{cd}}$ & $2.6^{\mathrm{d}}$ & $15^{\mathrm{c}}$ & $11^{\text {cde }}$ & $26^{\mathrm{c}}$ & $1^{\mathrm{c}}$ & $2^{\text {cde }}$ & $3^{\mathrm{c}}$ \\
\hline Saltbush leaves & $1.5^{\mathrm{c}}$ & $1.4^{\mathrm{bc}}$ & $3.0^{\mathrm{c}}$ & $19^{\mathrm{b}}$ & $13^{\mathrm{bc}}$ & $33^{\mathrm{b}}$ & $7^{\mathrm{b}}$ & $5^{\mathrm{bc}}$ & $12^{\mathrm{b}}$ \\
\hline Olive cake & $1.2^{\mathrm{d}}$ & $1.1^{\mathrm{de}}$ & $2.3^{\mathrm{d}}$ & $15^{\mathrm{c}}$ & $10^{\mathrm{def}}$ & $25^{\mathrm{c}}$ & $1^{\mathrm{c}}$ & $1^{\operatorname{def}}$ & $2^{\mathrm{c}}$ \\
\hline \multicolumn{10}{|l|}{ Fresh olive cake } \\
\hline $90 \mathrm{mg} \mathrm{N} \mathrm{kg}{ }^{-1}$ & $0.3^{\mathrm{g}}$ & $0.4^{\mathrm{g}}$ & $0.7^{\mathrm{g}}$ & $3^{\mathrm{e}}$ & $3^{h}$ & $6^{\mathrm{e}}$ & $-13^{\mathrm{e}}$ & $-9^{\mathrm{g}}$ & $-22^{\mathrm{e}}$ \\
\hline $22.5 \mathrm{mg} \mathrm{N} \mathrm{kg}^{-1}$ & $0.5^{\mathrm{f}}$ & $0.7^{\mathrm{f}}$ & $1.2^{\mathrm{f}}$ & $6^{\mathrm{de}}$ & $6^{\mathrm{g}}$ & $11^{\mathrm{d}}$ & $-40^{\mathrm{f}}$ & $-18^{\mathrm{h}}$ & $-58^{\mathrm{f}}$ \\
\hline SEM & 0.09 & 0.06 & 0.14 & 2.2 & 0.8 & 2.9 & 3.5 & 1.3 & 4.7 \\
\hline$P$ value & $<0.001$ & $<0.001$ & $<0.001$ & $<0.001$ & $<0.001$ & $<0.001$ & $<0.001$ & $<0.001$ & $<0.001$ \\
\hline
\end{tabular}

Means carrying no common superscript are different at $P<0.05$ (Tukey test)

$\psi \mathrm{N}$ use efficiency relative to barley grown in the $0 \mathrm{~N}$ control soils

$\mathrm{N}$ flow in the feed-animal-soil-plant system

The tested feeds resulted in retention of between 158 and $239 \mathrm{~g} \mathrm{~N} \mathrm{~kg}^{-1} \mathrm{~N}$ intake in the growing Awassi lambs (Fig. 2a). When compared to barley straw, fecal $\mathrm{N}$ excretion increased after feeding an olive leaf diet, while intake of saltbush leaf diet tended to increase urinary N. Due to the small amount of urine required for the compost mixtures, between 317 and $581 \mathrm{~g}$ urinary $\mathrm{N} \mathrm{kg}^{-1} \mathrm{~N}$ intake (32-58 \% of the total excreted $\mathrm{N})$ were unaccounted for in the analysis of $\mathrm{N}$ flows (Fig. 2b). Composting resulted in very variable $\mathrm{N}$ losses from less than $20 \%$ with the saltbush compost to more than half of the initial $\mathrm{N}$ available with the barley straw compost (Fig. 2c). Overall, compost amendment resulted in a positive but small uptake of $\mathrm{N}$ by the barley plants (6-28 $\mathrm{g} \mathrm{kg}^{-1} \mathrm{~N}$ intake), with the majority remaining unused in the soil (Fig. 2d). In contrast, the direct application of fresh feces as an amendment resulted in negative $\mathrm{N}$ uptake by the barley plants, leading to proportions of unused $\mathrm{N}$ ranging between 204 and $425 \mathrm{~g} \mathrm{~kg}^{-1} \mathrm{~N}$ intake (Fig. 2e). saltbush leaves and fresh olive cake, soils amended with compost made using feces from sheep fed these diets, or soils amended with fresh olive cake $(n=4)$ 


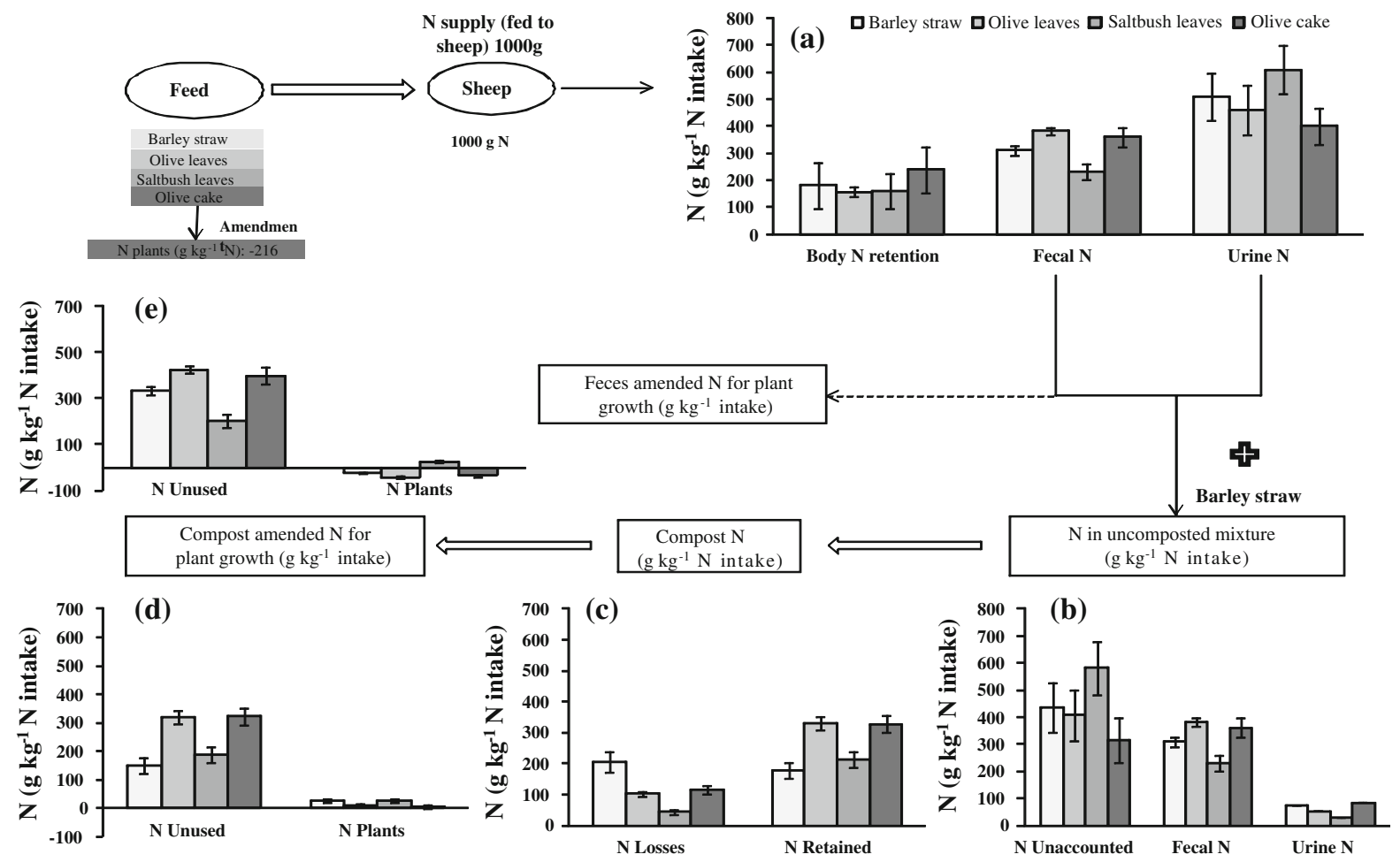

Fig. 2 Nitrogen flows in a feed-animal-soil-plant system, where barley straw, olive leaf, saltbush leaf and fresh olive cake diets are fed to Awassi sheep, and the feces and some urine are used to make compost to grow barley plants. Nitrogen flows from the feces to soil is also compared, but most of the urine $\mathrm{N}$ is unaccounted for in this experimental system about the implications of their use on overall $\mathrm{N}$ cycling in a mixed crop/livestock system.

Changes in amendment characteristics during composting as affected by the diet fed to sheep

The rate of $\mathrm{OM}$ degradation during composting depends on the content of readily biodegradable compounds present in the compost (Sellami et al. 2008). This suggests that the OM in the feces of the sheep fed the saltbush leaf diet should be very degradable, as had been observed for most of the dietary $\mathrm{OM}$ in the digestive tract (Abbeddou et al. 2011a). The compost derived from the olive cake diet was higher in OM than other composts. Probably in particular lignin limited its degradation in the digestive tract as feces from olive cake diet contained $630 \mathrm{~g}$ neutral detergent fiber kg ${ }^{-1} \mathrm{DM}$, of which $170 \mathrm{~g} \mathrm{~kg}^{-1}$ DM were lignin (Abbeddou et al. 2011b). Additionally, an adverse action on digestion due to the phenols present in this feed had been assumed. The low degradability of $\mathrm{OM}$ in the compost derived from the olive cake was consistent with the low OM digestibility of dietary olive cake in the animal. It therefore appears that the properties controlling digestibility of feeds in the animal also control degradation of feces subsequent to excretion, such as during composting (Rufino et al. 2006). The $\mathrm{C} / \mathrm{N}$ ratios of most composts were in the recommended range of $<12$ (Cayuela et al. 2004) for a stable OM of the compost, while it was higher for the compost from the olive cake treatment. The $\mathrm{NH}_{4}{ }^{+}$concentration of all composts was less than $0.40 \mathrm{~g} \mathrm{~kg}^{-1}$ as expected (Cayuela et al. 2004).

Nitrogen retention after composting was greater than the average of $54 \%$ reported by Thomsen (2000) for all composts except the barley straw diet derived compost ( $46 \%$ of $\mathrm{N}$ in the uncomposted mixture retained after composting compared to 75,85 and $74 \%$ of $\mathrm{N}$ retained in olive leaf, saltbush leaf and olive cake derived composts; data not shown), but was in the range of 30-87\% reported by Rufino et al. (2006). 
Soil response to the different amendments

Increase in soil EC results from an increase in the electrolytes $\mathrm{Na}$ and K (Mekki et al. 2006), and saltbush leaves are reported to have high contents of these cations (Abbeddou et al. 2011a). An ingested excess of electrolytes is mostly excreted in urine, which explains the elevated EC of both the compost and the soil of the saltbush leaf treatment. Fresh feces from the saltbush leaf diet also had a high $\mathrm{K}$ content (Table 3).

Net $\mathrm{N}$ mineralization in compost amended soils was similar to net mineralization in the $0 \mathrm{~N}$ soil. The $\mathrm{N}$ immobilization observed with all feces (except that from the saltbush leaves diet) agrees with Wichern et al. (2004), where fresh sheep and goat feces from local farms in Oman resulted in microbial $\mathrm{N}$ immobilization. Net $\mathrm{N}$ mineralization in soil treated with feces from the saltbush diet may have resulted from relatively low $\mathrm{C} / \mathrm{N}$ ratio and phenol content, and high mineral $\mathrm{N}$ content of this feces. Mineralization of $\mathrm{N}$ was related to the $\mathrm{C} / \mathrm{N}$ ratio of manures as found by Powell et al. (2006). Manures with $\mathrm{C} / \mathrm{N}$ ratios greater than 19 caused immobilization of soil $\mathrm{N}$, as was observed here with most of the feces having $\mathrm{C} / \mathrm{N}$ ratios between 22 and 32 , while manures with $\mathrm{C} / \mathrm{N}$ ratio less than 16 caused $\mathrm{N}$ mineralization. Mineralization of $\mathrm{N}$ might have been further reduced by the presence of polyphenols, especially after amendment by fresh olive cake and feces from the olive cake and leaf diets. Although olive cake has a moderate total phenol content, the special nature of the constitutive phenols (e.g., hydroxytyrosol, tyrosol, and their glucosides) makes it highly antimicrobial (Benitez et al. 2004; Cayuela et al. 2004; Sampedro et al. 2004). Additionally, phenols may bind proteins which are then protected from microbial degradation in the soil as for the rumen (van Bruchem et al. 1999; Tiemann et al. 2009). A regression analysis of all amendments in this study showed that $\mathrm{N}$ mineralization was negatively related to total amendment phenol input $(\mathrm{r}=-0.75, P=0.012)$.

Plant response to the experimental amendments

In the present study $77 \%$ of mineral fertilizer $\mathrm{N}$ was recovered in the barley roots and shoots, which is in the range of a pot study with ryegrass (Langmeier et al. 2002) but higher than $\mathrm{N}$ recovery of a barley crop growing in lysimeters (36\% on coarse sand to $49 \%$ on sandy loam soil; Thomsen et al. 1997) and recoveries in crops reported from field studies which usually are in the range of 20-50 \% (Crews and Peoples 2005). The NUE for animal manure is usually lower than that of mineral $\mathrm{N}$, because it is mainly composed by organic $\mathrm{N}$ forms which are not readily available to plants. In a pot study six harvests of ryegrass recovered 25-30 \% of N applied with fresh cow feces (Langmeier et al. 2002), while wheat growing in microplots in the field recovered $10 \%$ of $\mathrm{N}$ applied with sheep feces (Bosshard et al. 2009). Also in a microplot field study, barley at maturity (grain and straw) recovered $6 \%$ of $\mathrm{N}-15$ added with sheep feces (Jensen et al. 1999). In this experiment, the application of fresh feces reduced plant productivity compared to the $0 \mathrm{~N}$ soil, resulting in negative NUE except for the amendments from the saltbush leaf treatments. This could be explained by the higher amounts of mineral $\mathrm{N}\left(\mathrm{NH}_{4}-\mathrm{N}, \mathrm{NO}_{3}-\mathrm{N}\right)$ found in the feces from the saltbush leaf treatment than the other fecal amendments, and organic fecal $\mathrm{N}$ compounds that can be easily mineralized (Bosshard et al. 2011).

In contrast to the feces, a positive NUE was observed for all composts resulting in $\mathrm{N}$ recoveries in barley of $2-16 \%$ of the $\mathrm{N}$ applied. This is in the range found for fresh feces in other studies but much less than that reported for slurry composed of all of the feces and urine excreted (Langmeier et al. 2002; Bosshard et al. 2009). The NUE of both olive feed containing diets was lower than those from the barley straw and the saltbush based diet. In their review, Rufino et al. (2006) reported that NUE from composted manure for maize crops in Africa ranged between 3 and $49 \%$, with NUE being higher when urine was included in the composted manure. Nitrogen recovery from compost was higher than from fresh feces probably because soil amended with compost had higher total mineral $\mathrm{N}$ than the soil amended with feces. Also, compost had lower phenol contents than feces; the latter also because of dilution by urine and straw. Urine $\mathrm{N}$ mostly consists of urea which is a readily available $\mathrm{N}$ source for plants (Bosshard et al. 2009). However, part of the urea $\mathrm{N}$ gets hydrolyzed during composting (Thomsen 2000; Wichern et al. 2004) and lost in the form of ammonia (Rufino et al. 2006). The high $\mathrm{pH}$ in composts and soils may further have intensified ammonia volatilization. As no ${ }^{15} \mathrm{~N}$ labeling was done in the present study, $\mathrm{N}$ derived from feces and urine, and their respective contribution to barley $\mathrm{N}$ uptake (Bosshard et al. 2009), cannot be separated. 
The NUE of fresh olive cake was negative, indicating that the $\mathrm{N}$ in olive cake was not directly available for the plants and that olive cake amendment reduced the availability of soil $\mathrm{N}$. The inhibitory effect on plant productivity was less pronounced when less olive cake was added ( $1 / 4$ of the $\mathrm{N}$ dose used in the other treatments). This suggests that feeding olive cake may be relatively more advantageous than use of fresh olive cake as an amendment. When olive cake passes through the rumen and the digestive track, phenols are either metabolized or diluted when mixed with other feed ingredients resulting in excreta that might be less inhibitory to plant growth.

Amendment $\mathrm{N}$ not taken up by the crops can remain in the soil (Powell et al. 2006) or be lost from the soilplant system. Studies using ${ }^{15} \mathrm{~N}$ labeling show that with organic amendments often more $\mathrm{N}$ is recovered in the soil than with mineral fertilizer N (Sørensen and Thomsen 2005; Gardner and Drinkwater 2009). This is also supported by the studies by Langmeier et al. (2002) and Bosshard et al. (2009), where about $60 \%$ of $\mathrm{N}$ applied with fresh cattle or sheep feces remained in the soil. This $\mathrm{N}$ can become available to subsequent crops (Schröder et al. 2005) although at low release rates. Accordingly, only around 3.3 and $1.5 \%$ of feces $\mathrm{N}$ were recovered during the two following years in the study by Bosshard et al. (2009). The difference method used in this study does not allow measurement of amendment $\mathrm{N}$ recovery in the soil compared to the background soil $\mathrm{N}$.

Nitrogen flow in the feed-animal-soil-plant system as affected by unconventional feeds

The NUE of a mixed crop/livestock system is the result of $\mathrm{N}$ conversion at the animal level and the apparent $\mathrm{N}$ recovery from soil amended by animal excreta (van Bruchem et al. 1999). The calculated $N$ conversion efficiency at the animal level for growth (body $\mathrm{N}$ retention, Fig. 2a) was in the range of 150-250 $\mathrm{g} \mathrm{N} \mathrm{kg}^{-1} \mathrm{~N}$ intake reported by van Bruchem et al. (1999). All diets had similar $\mathrm{N}$ conversion efficiencies despite the lowest $\mathrm{N}$ intake associated with the saltbush leaves and olive cake diets (data taken from Abbeddou et al. 2011a, b). Nitrogen not converted into animal products (milk or body weight gain) is excreted with urine and feces, but also the allocation of excretory $\mathrm{N}$ to feces and urine clearly varied between treatments due to phenol content in the diets. As stated above, proteins bound to phenols are indigestible complexes excreted in feces where they constitute the insoluble $\mathrm{N}$ fraction (Powell et al. 1994). Based on the allocation of the excretory $\mathrm{N}$, the lowest feces $\mathrm{N}$ as a proportion of $\mathrm{N}$ intake was found with the saltbush diet $(P<0.001)$ and the highest with diets containing olive-derived feeds. Not all $\mathrm{N}$ excreted by the animals was included in manure $\mathrm{N}$ flow. Thus a large proportion of $\mathrm{N}$ excreted, i.e., urinary $\mathrm{N}$ with high plant availability, remained unaccounted for (32-58 \% of the total excreted N; Fig. 2b). Our experiment mimicked a situation where all feces would be collected, but where the urine not absorbed by the straw would have been lost. Farming systems with sheep in Syria are quite variable (Rischkowsky et al. 2004), and in turn the collection and use of animals excreta differs between farms and production areas. Likewise, straw is a limited valuable resource, and compost preparation and application may economically not always be viable as straw is in demand as livestock fodder (Sommer et al. 2011). Thus its use as animal bedding in barn is not always applied, especially in seasons with low barley straw yields.

In this study, the NUE of composts and of feces was tested when used as amendments for crop production. As discussed above, NUE by barley of both forms was low or even negative and a large fraction of applied $\mathrm{N}$ remained unused (Fig. 2d, e). The question arises whether the feces and urine would be better used on the rangelands than for crop production. We have no exact data on the proportion of $\mathrm{N}$ deposited in the rangelands compared with in the barns. Rufino et al. (2006) estimated that less than $50 \%$ of total $\mathrm{N}$ excreted can be collected in typical mixed grazingbarn system by smallholders in the sub-Saharan Africa. Based on experimental data of excreta collection and $\mathrm{N}$ loss during composting in central Kenya (Lekasi et al. 2001), Rufino et al. (2006) assumed that less than $10 \%$ of $\mathrm{N}$ in the excreta would be efficiently used in the mixed crop-livestock system in Kenya. Nitrogen deposited in the rangeland can be taken up by plants, be retained in the soil or be lost. Plant $\mathrm{N}$ uptake is limited to the short (up to 3 months in the dry areas of Syria) growing season when water availability sustains plant growth and nutrient uptake. During the 6 month-long dry period, particularly urine $\mathrm{N}$ deposited on the alkaline soils of the study area may largely be lost by ammonia volatilization. For instance, Vallis et al. (1985) reported a loss of $46 \%$ of urine $\mathrm{N}$ when 
cattle urine was applied on pasture during the dry season in Australia. Under these conditions, $\mathrm{N}$ cycling could be increased when a higher proportion of $\mathrm{N}$ is excreted with feces because feces $\mathrm{N}$ takes longer time to be mineralized and therefore the risk of ammonia volatilization is lower (Powell et al. 1994; Rufino et al. 2006). Based on this, diets containing olive-derived feeds seemed more efficient than the other diets, especially the saltbush leaf based diet which resulted in the highest proportion of $\mathrm{N}$ excreted in urine. Still it has to be shown whether $\mathrm{N}$ from olive cake and olive cake derived feces will be available in subsequent years or whether the compositional limitations prevent its release even longer.

\section{Conclusions}

Providing unconventional feeds to sheep only slightly affected the NUE by barley of N applied with feces or composts produced from feces, urine and straw, with NUE being higher after treatments with composts than with feces. The NUE obtained in the pot experiment was low or even negative, leaving most of the $\mathrm{N}$ applied unused. Feeding olive cake was more efficient as some nutrients were supplied when fed to the sheep increasing overall $\mathrm{N}$ cycling efficiency compared with its direct application as soil amendment. Labeling studies with ${ }^{15} \mathrm{~N}$ to separate unused $\mathrm{N}$ into $\mathrm{N}$ retained in soil and $\mathrm{N}$ losses are needed, as well as long-term plant experiments under field conditions to test residual amendment $\mathrm{N}$ effects. Although reflecting the limited collection practiced on farm, an important proportion of urine $\mathrm{N}$ was not considered in the present study. When the intention is to use amendments consisting of animal excreta strategically for crop production and in the growing season, it seems worthwhile to capture as much urine as possible and, therefore, to change excreta storage and application practices.

Acknowledgments This work was funded by the Swiss Development Cooperation, Berne, through the North-South Center, ETH Zurich, Switzerland. We are grateful to Thomas Flura from the plant nutrition group (ETH Zurich) for his help to set up the experiment and his technical advice during soil and plant analysis. Our thanks go to George Estefan, Ahmed Sawass and their teams from ICARDA for their technical help during the whole experiment and to Rolf Sommer (ICARDA) and the anonymous reviewers for the helpful comments on our manuscript.

\section{References}

Abbeddou S, Rihawi S, Hess HD, Iñiguez L, Mayer AC, Kreuzer M (2011a) Nutritional composition of lentil straw, vetch hay, olive leaves and saltbush leaves, and their digestibility as measured in fat-tailed sheep. Small Rum Res 96:126-135

Abbeddou S, Rihawi S, Zaklouta M, Hess HD, Iñiguez L, Kreuzer M (2011b) Ruminal degradability, digestibility, energy content, and influence on $\mathrm{N}$ and mineral turnover of various Mediterranean by-products in fat-tailed Awassi sheep. Anim Feed Sci Technol 163:99-110

AOAC (1997) Official methods of analysis. Association of Official Analytical Chemists, Arlington

Benitez E, Melgar R, Nogales R (2004) Estimating soil resilience to a toxic organic waste by measuring enzyme activities. Soil Biol Biochem 36:1615-1623

Bosshard C, Sørensen P, Frossard E, Dubois D, Mäder P, Nanzer S, Oberson A (2009) Nitrogen use efficiency of ${ }^{15} \mathrm{~N}$-labelled sheep manure and mineral fertilizer applied to microplots in long-term organic and conventional cropping systems. Nutr Cycl Agroecosyst 83:271-287

Bosshard C, Oberson A, Leinweber P, Jandl G, Knicker H, Wettstein H-R, Kreuzer M, Frossard E (2011) Characterization of fecal nitrogen forms produced by a sheep fed with ${ }^{15} \mathrm{~N}$ labeled ryegrass. Nutr Cycl Agroecosyst 90:355-368

Bremner JM, Keeney DR (1965) Steam distillation methods for determination of ammonium, nitrate, and nitrite. Anal Chim Acta 32:485-495

Cayuela ML, Bernal MP, Roig A (2004) Composting olive mill waste and sheep manure for orchard use. Compost Sci Util 12:130-136

Crews TE, Peoples MB (2005) Can the synchrony of nitrogen supply and crop demand be improved in legume and fertilizer-based agroecosystems? A review. Nutr Cycl Agroecosyst 72:101-120

El Shaer HM (2010) Halophytes and salt-tolerant plants as potential forage for ruminants in the Near East region. Small Rum Res 91:3-12

Fliessbach A, Oberholzer HR, Gunst L, Mader P (2007) Soil organic matter and biological soil quality indicators after 21 years of organic and conventional farming. Agric Ecosyst Environ 118:273-284

Frossard E, Bünemann EK, Carsky R, Compaoré E, Diby LN, Kouamé VH, Oberson A, Taonda SJ-B (2006) Integrated nutrient management as a tool to combat soil degradation in Sub Saharan Africa. In: Bearth T, Becker B, Kappel R, Krüger G, Pfister R (eds) Afrika im Wandel. vdf Hochschulverlag Zurich, pp 137-146

Gardner JB, Drinkwater LE (2009) The fate of nitrogen in grain cropping systems: a meta-analysis of ${ }^{15} \mathrm{~N}$ field experiments. Ecol Appl 19:2167-2184

Harmsen K (2003) A comparison of the isotope-dilution and the difference method for estimating fertilizer nitrogen recovery fractions in crops. I. Plant uptake and loss of nitrogen. Neth J Agric Sci 50:321-347

Jensen B, Sorensen O, Thomsen IK, Jensen ES, Christensen BT (1999) Availability of nitrogen in N-15-labeled ruminant manure components to successively grown crops. Soil Sci Soc Am J 63:416-423 
Keeney DR, Nelson DW (1982) Nitrogen-inorganic forms. In: Page AL et al (eds) Methods of soil analysis. Part 2, 2nd edn. Agron. Monogr. 9, ASA and SSSA, Madison, WI, pp 643-698

Langmeier M, Frossard E, Kreuzer M, Mäder P, Dubois D, Oberson A (2002) Nitrogen fertilizer value of cattle manure applied on soils originating from organic and conventional farming systems. Agronomie 22:789-800

Lekasi JK, Tanner JC, Kimani SK, Harris PJC (2001) Managing manure to sustain smallholder livelihoods in the East African high-lands. HDRA, Coventry

Louhaichi M, Tastad A (2010) The Syrian steppe: past trends, current status, and future priorities. Rangelands 32:2-7

Makkar HPS (2003) Quantification of tannins in tree and shrub foliage, a laboratory manual. Kluwer, Dordrecht

Mekki A, Dhouib A, Sayadi S (2006) Changes in microbial and soil properties following amendment with treated and untreated olive mill wastewater. Microbiol Res 161: 93-101

Molina-Alcaide E, Nefzaoui A (1996) Recycling of olive oil byproducts: possibilities of utilization in animal nutrition. Int Biodeterior Biodegrad 38:227-235

Molina-Alcaide E, Yáñez-Ruiz DR (2008) Potential use of olive by-products in ruminant feeding: a review. Anim Feed Sci Technol 147:247-264

Oktay Z (2006) Olive cake as a biomass fuel for energy production. Energ Sour Part A 29:329-339

Olsen SR, Cole CV, Watanabe FS, Dean LA (1954) Estimation of available phosphorus in soils by extraction with sodium bicarbonate. United States Department of Agriculture, Washington DC, pp 171-188

Powell JM, Fernández-Rivera S, Hofs S (1994) Effects of sheep diet on nutrient cycling in mixed farming systems of semiarid West Africa. Agric Ecosyst Environ 48:263-271

Powell JM, Wattiaux MA, Broderick GA, Moreira VR, Casler MD (2006) Dairy diet impacts on fecal chemical properties and nitrogen cycling in soils. Soil Sci Soc Am J 70: 786-794

Richards LA (1954) Diagnosis and improvement of saline and alkali soils. USDA Agric Handbook 60. Washington, DC

Rischkowsky B, Thomson EF, Shnayien R, King JM (2004) Mixed farming systems in transition: the case of five villages along a rainfall gradient in North-West Syria. Expl Agric 40:109-126

Roig A, Cayuela ML, Sànchez-Monedero MA (2006) An overview on olive mill wastes and their valorisation methods. Waste Manage 26:960-969

Rufino MC, Rowe EC, Delve RJ, Giller KE (2006) Nitrogen cycling efficiencies through resource-poor African croplivestock systems. Agric Ecosyst Environ 112:261-282

Ryan J, Masri S, Garabet S, Diekmann J, Habib H (1997) Soils of ICARDA's agricultural experiment stations and sites, Climate, chemical and physical properties, and land management. ICARDA, Aleppo, Syria. Tech. Bull., p 107

Sampedro I, Romero C, Ocampo JA, Brenes M, García I (2004) Removal of monomeric phenols in dry mill olive residue by saprobic fungi. J Agric Food Chem 52:4487-4492
Sangaré M, Bationo A, Hiernaux P, Fernández-Rivera S, Pandey V (2002) Effect of type and level of roughage offered to sheep and urine addition on compost quality and millet growth and production in the Sahel. Nutr Cycl Agroecosys 62:203-208

Sansoucy R (1985) Olive by-products for animal feed. Online: FAO Animal Production and Health Paper No. 43 (accessed 31.12.11) www.fao.org/docrep/003/X6545E/X6545E00.htm

Schröder JJ, Jansen AG, Hilhorst GJ (2005) Long-term nitrogen supply from cattle slurry. Soil Use Manage 21:196-204

Sellami F, Jarboui R, Hachicha S, Medhioub K, Ammar E (2008) Co-composting of oil exhausted olive-cake, poultry manure and industrial residues of agro-food activity for soil amendment. Bioresour Technol 99:1177-1188

Sommer R, Ryan J, Masri S, Singh M, Diekmann J (2011) Effect of shallow tillage, moldboard plowing, straw management and compost addition on soil organic matter and nitrogen in a dryland barley/wheat-vetch rotation. Soil Till Res 115-116:39-46

Sørensen P, Thomsen IK (2005) Separation of pig slurry and plant utilization and loss of nitrogen-15-labeled slurry nitrogen. Soil Sci Soc Am J 69:1644-1651

Thomsen IK (2000) $\mathrm{C}$ and $\mathrm{N}$ transformations in ${ }^{15} \mathrm{~N}$ crosslabelled solid ruminant manure during anaerobic and aerobic storage. Bioresour Technol 72:267-274

Thomsen IK, Kjellerup V, Jensen B (1997) Crop uptake and leaching of $\mathrm{N}-15$ applied in ruminant slurry with selectively labelled faeces and urine fractions. Plant Soil 197: 233-239

Tiemann TT, Hincapie B, Frossard E, Kreuzer M, Hess HD (2009) Effect of supplementing tropical tannin-free and tanniniferous legumes to grass-fed sheep on the utility of their manure as nitrogen fertilizer. Livest Res Rural Dev 21 http://www.lrrd.org/lrrd21/3/tiem21041.htm

Vallis I, Peake DCI, Jones RK, McCown RL (1985) Fate of urea-nitrogen from cattle urine in a pasture-crop sequence in a seasonally dry tropical environment. Aust J Agric Res 36:809-817

van Bruchem J, Verhoeven F, Brussaard L, Tamminga S (1999) Diet and manure characteristics in relation to nitrogen flows in a dairy farming system. In: van der Heide D, Huisman EA, Kanis E, Osse JWM, Verstegen MWA (eds) Regulation of feed intake. Proceedings of the 5th Zodiac Symposium 22-24 April 1998, Wageningen, The Netherlands, pp 219-225

Walkley A (1947) A critical examination of a rapid method for determining organic carbon in soils: effect of variations in digestion conditions and of organic soil constituents. Soil Sci 63:251-263

Wichern F, Müller T, Joergensen RG, Buerkert A (2004) Effects of manure quality and application forms on soil $\mathrm{C}$ and $\mathrm{N}$ turnover of a subtropical oasis soil under laboratory conditions. Biol Fertil Soils 39:165-171 